\title{
Inhibitory effects of aromatase inhibitor on estrogen receptor-alpha positive ovarian cancer in mice
}

\author{
Hachidai Hirakawa', Yoshihito Yokoyama ${ }^{1 *}$, Hidemi Yoshida ${ }^{2}$ and Hideki Mizunuma ${ }^{1}$
}

\begin{abstract}
Background: Estrogen causes proliferation of ovarian cancer cells. Although hormone therapy with an antiestrogen agent is an optional therapy for recurrent epithelial ovarian cancers, both basic and clinical researches are insufficient. We here examine the efficacy of an aromatase inhibitor (Al) for peritonitis carcinomatosa, the late stage of ovarian cancer.
\end{abstract}

Methods: Estrogen receptor (ER)a was assayed in four ovarian cancer cell lines by the RT-PCR method. Using ovariectomized nude mice, peritonitis carcinomatosa consisting of OVCAR-3 cells with the strongest ERa expression or DISS cells with weaker ERa expression was prepared. The survival period was compared between the letrozole group ( $5 \mathrm{mg} / \mathrm{kg} /$ day orally; $n=10)$ and the control group $(n=10)$. In addition, the degree of angiogenesis and occurrence of apoptosis were compared using tumor tissue from the abdominal cavity. The expression of aromatase and the protein involving in ERa signaling were examined in tumors immunohistochemically.

Results: Survival period in OVCAR-3 tumors was significantly prolonged in the letrozole group, compared with the control group $(P<0.05)$, whereas that in DISS tumors was not different between the both groups. The microvessel density in tumors and expression of VEGF decreased significantly in the letrozole group compared to the control group. The incidence of apoptosis did not differ significantly between these groups. No adverse event was observed accompanying the administration of letrozole. The expressions of aromatase, ERa and FOXP1 that is associated with ERa signaling were reduced in tumors by letrozole administration.

Conclusions: Letrozole was effective for ovarian cancers with abundant expression of ERa. Inhibition of angiogenesis and of ascites production appeared to contribute to prolongation of the survival period.

Keywords: Recurrent ovarian cancer, Letrozole, Estrogen receptor alpha, Aromatase inhibitor, Anti-angiogenesis

\section{Background}

Ovarian cancer is still the most lethal of all gynecologic cancers. The American Cancer Society estimated that about 22,240 new cases of ovarian cancer will be diagnosed and 14,030 women will die of ovarian cancer in the United States in 2013 [1]. There are various methods for treating of recurrent ovarian cancer and chemotherapeutic regimen is chosen based on platinum susceptibility but there is no established second-line therapy.

\footnotetext{
* Correspondence: yokoyama@cc.hirosaki-u.ac.jp

${ }^{1}$ Department of Obstetrics and Gynecology, Hirosaki University Graduate

School of Medicine, 5 Zaifu-cho, Hirosaki, Aomori 036-8261, Japan

Full list of author information is available at the end of the article
}

In the National Comprehensive Cancer Network $(\mathrm{NCCN})$ guidelines (version 3, 2012), hormone therapy is classified under "other drugs that are potentially effective" as "approved treatment for recurrent forms" of epithelial ovarian cancer. However, the number of clinical and basic studies of hormone therapy conducted for this disease is insufficient.

There is evidence that estrogen promotes proliferation of ovarian cancer in cell culture and a xenograft model [2-6]. Furthermore, it has been shown that the growth of ovarian cancer cells is inhibited in vivo and in vitro by the anti-estrogen therapy directed at estrogen receptor (ER) positive OVCAR-3 cells [3,5,6].
C Biomed Central

(c) 2014 Hirakawa et al.; licensee BioMed Central Ltd. This is an Open Access article distributed under the terms of the Creative Commons Attribution License (http://creativecommons.org/licenses/by/2.0), which permits unrestricted use, distribution, and reproduction in any medium, provided the original work is properly cited. The Creative Commons Public Domain Dedication waiver (http://creativecommons.org/publicdomain/zero/1.0/) applies to the data made available in this article, unless otherwise stated. 
There are two types of ER $\alpha$ and ER $\beta$. ER $\alpha$ is expressed in up to $60 \%$ of ovarian cancers [7]. ER $\alpha$ activates expression of genes that are involved in cell survival and proliferation, whereas the function of $\operatorname{ER} \beta$ has been found to be antiproliferative [8]. Because the growth response in ovarian cancer cell lines is mediated by ER $\alpha$ but not by $\operatorname{ER} \beta[5,9]$, treatment with an ER $\alpha$ specific agonist (PTT,4',4',4' (4-(4-Propyl-[1H]-pyrazole-1,2,5-tryl)trisphenol) promotes cell proliferation [5].

Aromatase converts adrenal androstenedione to estrogen and is expressed in fat, liver, muscle and cancers such as the breast and the ovary [10]. Intra-tumoral estrogens derived from in situ aromatization act as an autocrine growth factor that promotes cancer cell proliferation independent of circulating estrogen [11]. Aromatase inhibitors (AIs) inhibit estrogen production in postmenopausal women by more than 90\%. Expression of aromatase mRNA and the aromatase protein itself have been found in $33-81 \%$ of ovarian cancers $[12,13]$.

The therapeutic effect of AIs has been shown to be superior to that of tamoxifen as adjuvant therapy for breast cancer [14]. In addition, in vitro studies showed an anti-tumor effect of AI on ovarian cancer cells, which was associated with aromatase activity and ER expression [15]. Letrozole is an oral non-steroidal AI and used for the treatment of local or metastatic breast cancer that is ER positive.

The present study was conducted to evaluate the efficacy of letrozole in the late stages of ER $\alpha$ positive ovarian cancer and elucidate the mechanism.

\section{Methods}

\section{Cell cines and cell culture}

OVCAR-3 derived from human ovarian papillary adenocarcinoma and TOV-112D derived from human ovarian endometrioid adenocarcinoma were obtained from the American Type Culture Collection (Rockville, MD). MCAS derived from human ovarian mucinous adenocarcinoma was obtained from Japanese Collection of Research Bioresources Cell Bank (Osaka, Japan). DISS derived from human ovarian serous adenocarcinoma was kindly provided by Dr. Saga (Jichi Medical School, Tochigi, Japan) [16]. All of these cell lines were grown in RPMI 1640 medium supplemented with 10\% fetal bovine serum, $100 \mathrm{U} / \mathrm{ml}$ penicillin and $100 \mu \mathrm{g} / \mathrm{ml}$ streptomycin at $37^{\circ} \mathrm{C}$ in a water-saturated atmosphere with $5 \% \mathrm{CO}_{2} / 95 \%$ air. All cell lines used in this study are authenticated as being ovarian in origin with a written guarantee.

\section{Animal experimentation}

Animal experiments were conducted in accordance with the Guidelines for Animal Experimentation, Hirosaki University. Eight-week-old female BALB/c nu/nu mice were used in this study. At the Institute for Animal Experimentation of Hirosaki University, all mice were group-housed in plastic cages with stainless-steel grid tops, under a 12-hour light dark cycle and consumed water and food ad libitum.

\section{Hormone administration and ovariectomy}

Letrozole was purchased from Novartis Oncology (Tokyo, Japan). Letrozole was suspended in distilled water $(0.88 \mathrm{mmol} / \mathrm{l})$. The experimental mice were divided into two groups containing ten mice each. The letrozole group was given letrozole $5 \mathrm{mg} / \mathrm{kg} /$ day by oral gavage every day until the end of the study, and the control group was given vehicle. Bilateral ovariectomy was performed under pentobarbital anesthesia in all experimental mice on the seventh day after commencement of letrozole administration.

\section{Real-time quantitative PCR}

Total RNA was extracted from the cells using an Illustra RNAspin Mini RNA Isolation Kit (GE Healthcare, Piscataway, NJ). Total RNA ( $4 \mu \mathrm{g})$ served as a template for single-strand cDNA synthesis in a reaction using an iScript Advanced cDNA Kit (Bio-Rad, Hercules, CA) under the conditions [17] with slight modifications. A CFX96 real-time PCR detection system (Bio-Rad) was used for the quantitative analyses of ER $\alpha$ and glyceraldehyde-3phosphate dehydrogenase (GAPDH). The sequences of the primers were as follows:

\section{ER $\alpha-F$ (5'-TGGGCTTACTGACCAACCTG-3'), ER $\alpha-R$ (5'-CCTGATCATGGAGGGTCAAA-3'), GAPDH-F (5'-ACCACCAACTGCTTAGCACC-3'), and GAPDH-R (5'-CCATCCACAGTCTTCTGGGT-3').}

The amplification reactions were performed with SsoFast EvaGreen Supermix (Bio-Rad) according to the manufacturer's specifications. The primers were used at $300 \mathrm{nM}$. The amplification conditions were as follows: $30 \mathrm{sec}$ at $95^{\circ} \mathrm{C}$, followed by $95^{\circ} \mathrm{C}$ for $5 \mathrm{sec}$ and $60^{\circ} \mathrm{C}$ for $30 \mathrm{sec}$ for 40 consecutive cycles. After amplification, a melting curve $65^{\circ} \mathrm{C}$ to $95^{\circ} \mathrm{C}$ at $0.5^{\circ} \mathrm{C}$ increments and $5 \mathrm{sec}$ per step was generated with continuous monitoring of fluorescence. The melting curves and quantitative analysis of the data were performed using CFX manager Version 2.1 software (BioRad) [17].

\section{Evaluation of adverse effects following administration of letrozole}

The nude mice, ovariectomized at the age of nine weeks were given letrozole $(n=10)$ or its vehicle $(n=10)$ for five weeks. All mice were weighed every day and the consumption of food was measured daily. Acts of selfharm or aggression were also observed. 


\section{Mouse model of peritoneal carcinomatosis}

OVCAR-3 cells $\left(5.0 \times 10^{6}\right.$ cells $)$ or DISS cells $\left(5.0 \times 10^{6}\right.$ cells) were inoculated into the peritoneal cavity of ovariectomized nude mice in $500 \mu \mathrm{l}$ of RPMI 1640 medium at the age of nine weeks. The survival times for the letrozole and control groups were evaluated. The survival was compared until 5 weeks after cell inoculation and surviving mice were euthanized using high-dose pentobarbital in order to remove the peritoneal tumors for histologic and biochemical evaluation.

\section{Immunohistochemical analysis and microvessel density}

Six-micrometer sections of formalin-fixed and paraffinembedded tissue specimens were stained by an established method described previously [18]. Sections were incubated with antibodies specific for Factor VIII (DAKO, Tokyo, Japan), vascular endothelial growth factor (VEGF) ( $\mathrm{R} \&$ D Systems, Minneapolis, MN), cleaved caspase-3 (Santa Cruz Biotechnology, Santa Cruz, CA), human P450 aromatase (ARK Resource, Kumamoto, Japan), ER $\alpha$ (Santa Cruz Biotechnology) and FOXP1 (Abcam, Tokyo, Japan) at $4{ }^{\circ} \mathrm{C}$ overnight. Slides were incubated with biotinylated species-specific appropriate secondary antibodies for 30 minutes and exposed to avidin-biotin-peroxidase complex (VECTA Laboratories, Burlingame, CA). Sections were treated with $0.02 \% \mathrm{DAB}$ as a chromogen and counterstained with hematoxylin. Microvessel density (MVD) was determined as follows. The highly vascularized areas of the tumor stained with an anti-Factor VIII antibody were identified and Factor VIII-positive microvessels were counted within a high-power field (number per $0.75 \mathrm{~mm}^{2}$ ). Single endothelial cells or clusters of endothelial cells, with or without lumen, were considered individual vessels. MVD was expressed as the

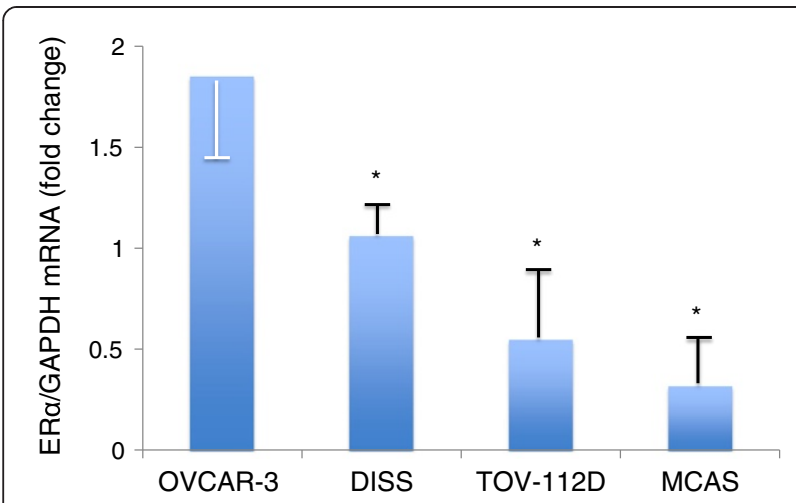

Figure 1 Determination of estrogen receptor-alpha (ERa) mRNA level in four ovarian cancer cell lines. The level of ERa mRNA was significantly higher in OVCAR-3 cells in comparison to the other three lines. ERa mRNA expression was normalized to GAPDH mRNA expression (DISS as control $=1$ ). Means \pm SD of three experiments are shown. ${ }^{*} P<0.05$ versus OVCAR-3. vessel number/high-power field in sections. Three fields were counted per animal and the average was taken as the MVD of each tumor.

\section{Weatern blot analysis}

Cell lysates (50 $\mu$ g protein) were prepared from tumor tissues, electrophoresed through a $12.5 \%$ SDS-polyacrylamide gel, and blotted as described previously [18]. The protein concentration was determined using Bradford's method. The blots were probed with the following diluted antibodies for $2 \mathrm{hr}$ : cleaved caspase-3 (active, 17KDa) at 1:1000 and $\beta$-actin (Sigma-Aldrich, St Louis, MO) at 1:2000. The membranes were then incubated for $1 \mathrm{hr}$ with the appropriate biotinylated secondary antibodies, transferred to avidin-biotin-peroxidase complex reagent, and incubated in this solution for $30 \mathrm{~min}$. Diaminobenzidine (Sigma-Aldrich) was used as a substrate.

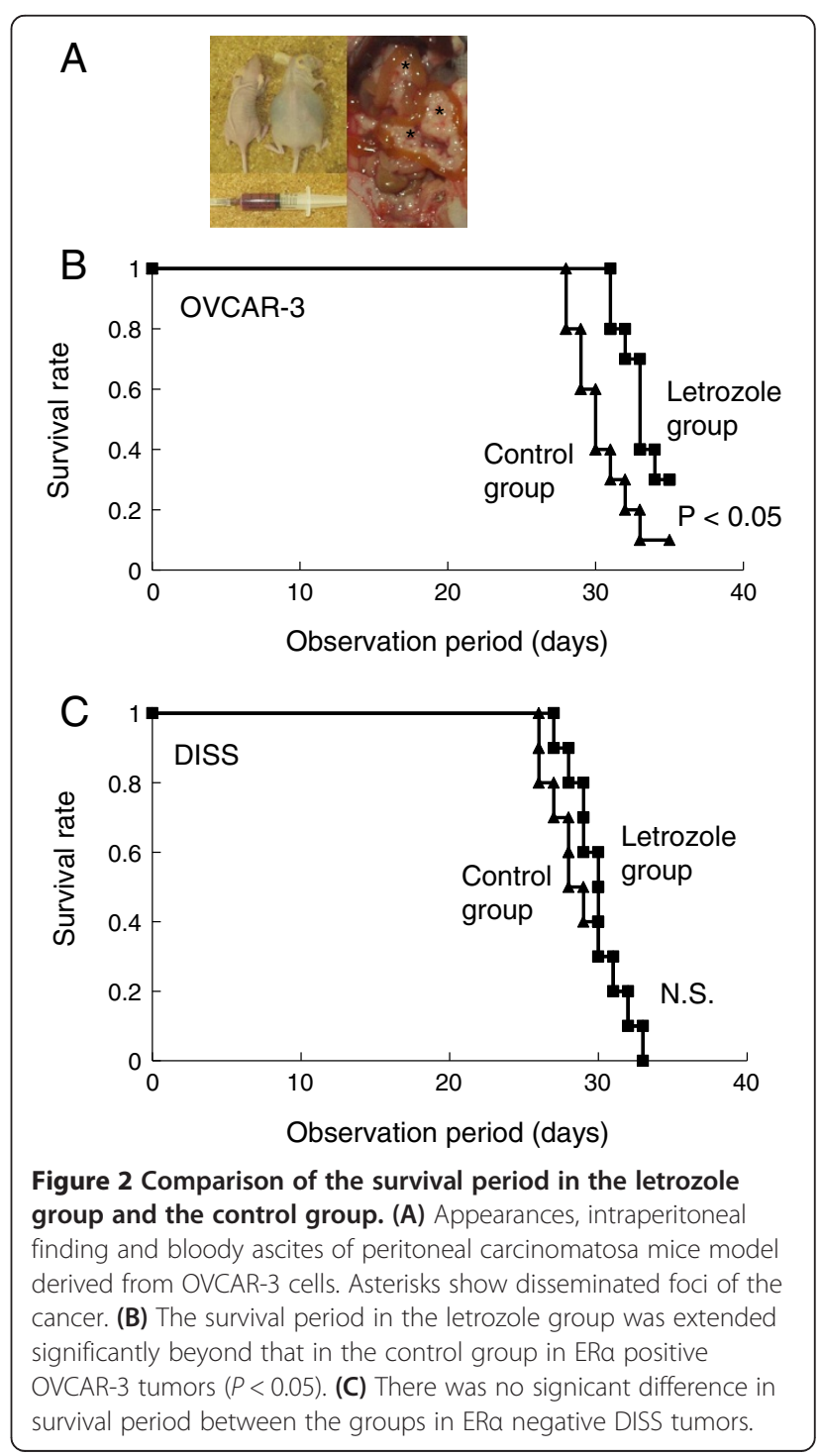




\section{Statistical analysis}

Survival rates were calculated by the Kaplan-Meier method, and the statistical significance of differences in the cumulative survival curves between the groups was evaluated using the log-rank test. Other statistical analysis was carried out with the Student $t$-test. A result was deemed significant at a $P$ value $<0.05$.

\section{Results}

\section{Comparison of mRNA expression of ERa in the ovarian} cancer cell lines

We determined mRNA abundance of ER $\alpha$ in four ovarian cancer cell lines using real-time quantitative PCR. We found that the level of ER $\alpha$ mRNAin OVCAR-3 cells was significantly higher than that in other three cell lines $(P<0.05$, Figure 1$)$. Thus, OVCAR-3 was defined as ER $\alpha$ positive, whereas DISS, MCAS and TOV$112 \mathrm{D}$ were defined as ER $\alpha$ negative.

\section{Evaluation of adverse effect caused by giving letrozole after ovariectomy}

Changes in the body weights of ovariectomized mice were evaluated. Body weights were $27.9 \pm 1.4$ in mice given letrozole for 5 weeks and $28.1 \pm 2.4$ in mice given vehicle, with no significant difference. All of the mice were healthy and did not exhibit self-harm or act aggressively.

\section{Comparison of survival period in peritonitis carcinomatosa derived from OVAR-3 cells or DISS cells}

Survival times were compared between the letrozole and the control groups in the peritonitis cacinomatosa (Figure 2A). Survival periods in ER $\alpha$ positive OVCAR-3 tumors were significantly prolonged in the letrozole group, compared with the control group $(P<0.05$, Figure $2 \mathrm{~B}$ ), whereas those in ER $\alpha$ negative DISS tumors were not different between the both groups (Figure $2 \mathrm{C}$ ).

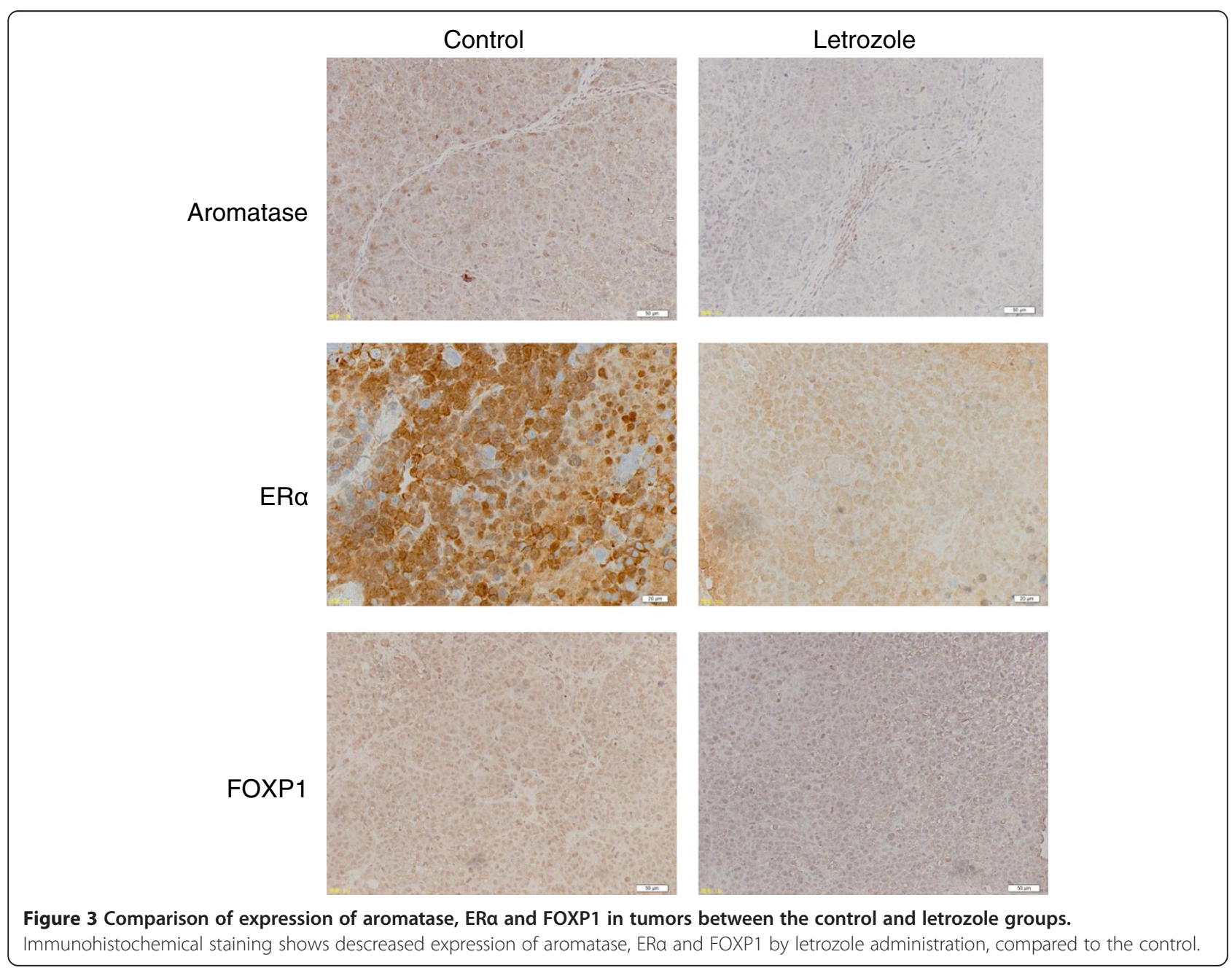




\section{Altered expression of aromatase, ERa and FOXP1 in tumors by letrozole}

We compared aromatase expression in tumors in order to examine whether letrozole administration affects in situ aromatization. Expressions of ER $\alpha$ and FOXP1 involving in ER $\alpha$ signaling [19] were also examined. Immunohistochemical analysis showed that expression of aromatase, ER $\alpha$ and FOXP1 in tumors was reduced by letrozole administration (Figure 3).

\section{Reduction of microvessel density and VEGF level in tumors by letrozole}

We examined the number of microvessels identified in tumor tissues using an immunostaining method for Factor VIII. MVD (number $/ \mathrm{mm}^{2}$ ) was $8.9 \pm 1.4$ for the control group, and $5.8 \pm 1.8$ for the letrozole group, showing a significant decrease in the letrozole group as compared with the control group $(P<0.05$, Figure $4 \mathrm{~A})$. Immunostaining showed a notable decrease in the expression of VEGF in tumors in the letrozole group, as compared with the control group (Figure 4B).

\section{Comparison of apoptotic cells identified with caspase-3 antibody and expression of caspase-3}

The number of apoptotic cells per $\mathrm{mm}^{2}$ was $320 \pm 32$ in the control group, and $272 \pm 32$ in the letrozole group, an insignificant difference between the groups (Figure 5A). Western blot also showed no significant difference of expressions of caspase-3 between the groups (Figure 5B).

\section{Discussion}

In this study, we prepared a model of peritonitis carcinomatosa, using ovariectomized nude mice and examined the effect of an AI on this condition, which occurs most frequently as a mode of postoperative recurrence of ovarian cancer. We found that the survival was extended significantly by the administration of letrozole in peritonitis carcinomatosa produced by inoculation of OVCAR-3 that

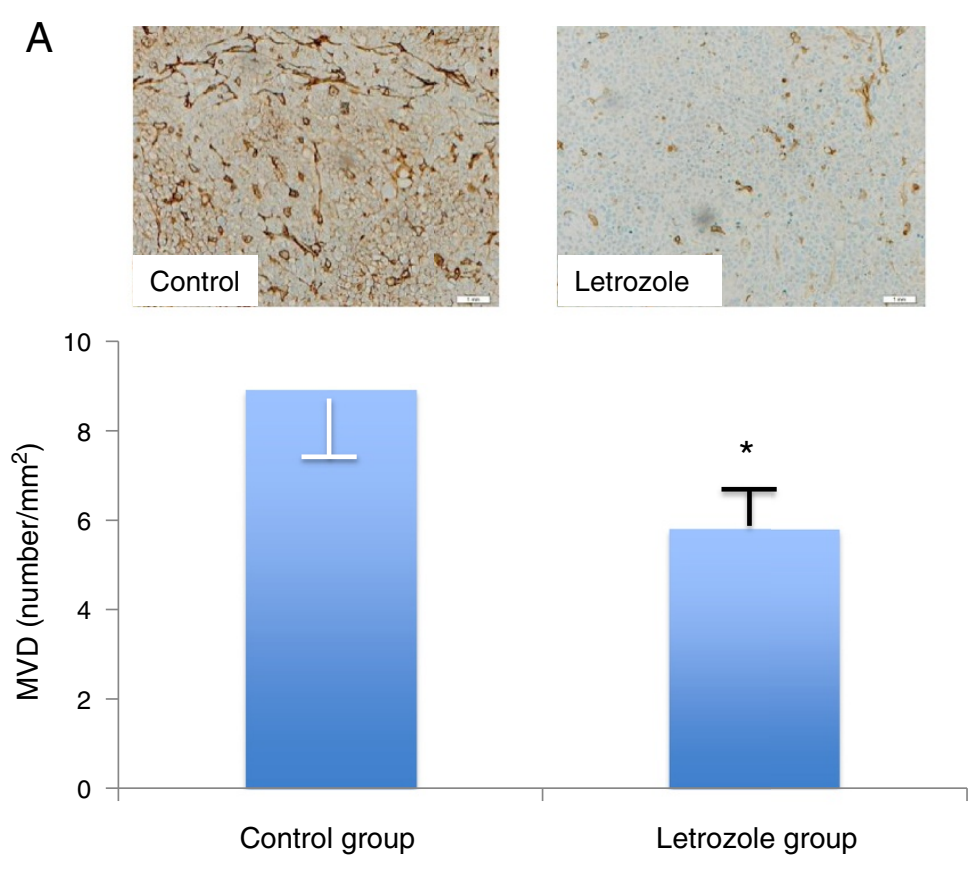

B
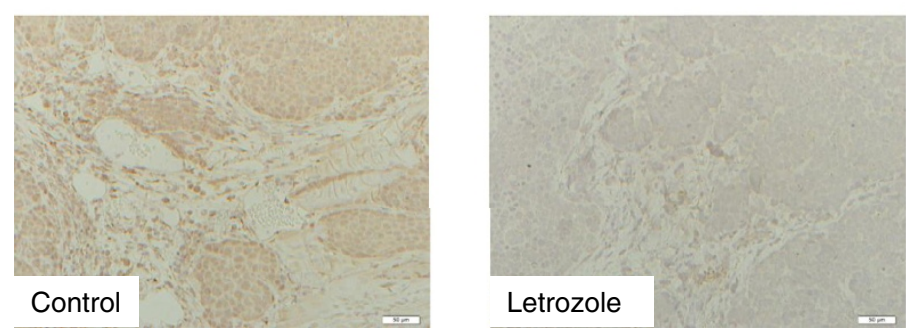

Figure 4 Comparison of microvessel density (MVD) and VEGF expression in the letrozole group and the control group. (A) The MVD in the letrozole group was significantly lower than that in the control group. ${ }^{*} P<0.05$. (B) VEGF expression in the letrozole group was remarkably lower than that in the control group. 

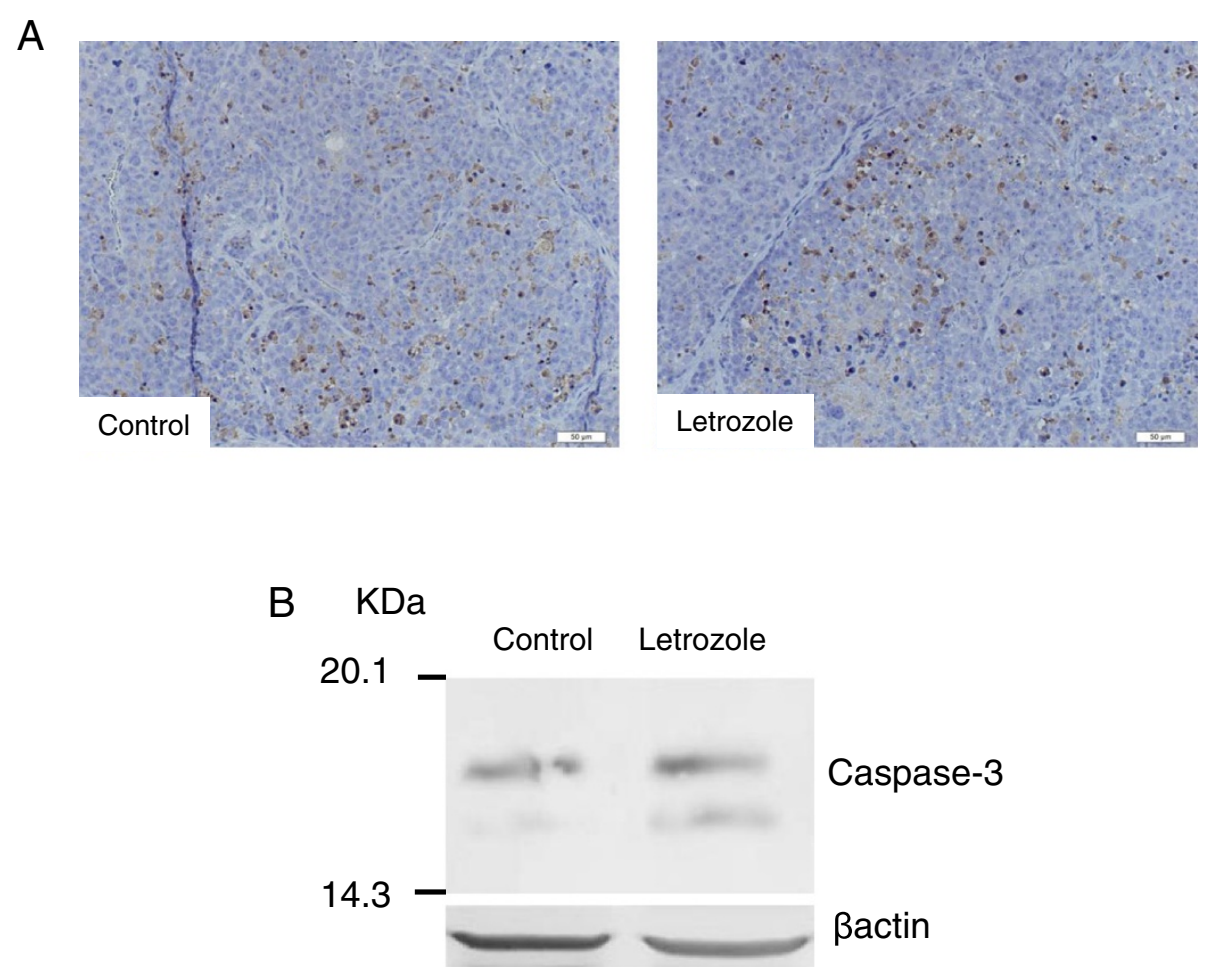

Figure 5 Apoptotic cells identified with caspase-3 antibody and expression of caspase-3. (A) Immunohistochemical staining. Brown-colored cells are an apoptotic cell identified with caspase-3 antibody. (B) Western blot. There is no significant difference in expressions of caspase-3 between the groups.

exhibited strongest ER $\alpha$ expression. As regards the mechanism of action, decreases in MVD and VEGF expression suggested that inhibition of both angiogenesis and production of ascites contributed to prolongation of survival.

It has been reported that VEGF plays an important role in angiogenesis and ascites production and the expression of VEGF is regulated by estrogen [20]. Presence of an estrogen-responsive element was established for the VEGF gene [21], and the contribution of estrogen to a direct increase in expression of the VEGF gene and angiogenesis has been demonstrated [22]. These results therefore indicate that estrogen accelerates tumor progression by means of VEGF. Conversely, AIs are shown to decrease the estrogen level in breast cancer tissues [23] and reduce VEGF in breast cancer cells [24]. The present study shows for the first time that the administration of an AI decreased VEGF and MVD in OVCAR3 that is derived from ovarian cancer. The present results provide evidence for inhibition of angiogenesis by the AI and indicate that inhibition of angiogenesis is the mechanism by which AIs suppress tumor proliferation. In breast cancers, estrogen and ER are involved in tumor proliferation and tumor proliferation is inhibited by the anti-estrogen activity [25]. Although it has not been shown in ovarian cancers that estrogen and ER are involved in tumor proliferation in a similar manner to breast cancers, an effect of AIs on ER-positive ovarian cancer can be expected based on the results of this study, which demonstrated inhibition of tumor proliferation in ER $\alpha$-positive ovarian cancers by the AI. In this study, expression of aromatase, ER $\alpha$ and FOXP1 in OVCAR-3 tumors was reduced by letrozole administration. Aromatization of androstendione may be inhibited in OVCAR-3 tumors by letrozole. FOXP1 is situated at a downstream of ER $\alpha$ signaling [19]. These results suggest that suppression of aromatization and ER $\alpha$ signaling in $\mathrm{ER} \alpha$-positive ovarian cancer by the AI may contribute to inhibition of tumor proliferation.

In vitro experiments using breast cancer cells have shown an induction of apoptosis by AIs [26], indicating that this is the mechanism of inhibition of breast cancer proliferation. AIs have also been reported to increase in vivo apoptosis significantly in combination with an mTOR inhibitor, thereby exhibiting an anti-tumor effect [27]. Amarai et al. have emphasized the importance of AIs as inducers of apoptosis, by effects on both mitochondria and caspase- 8 [28]. On the other hand, Bailey et al. have reported that the combination of an $\mathrm{AI}$ and an apoptosis inducer is an effective treatment strategy for ER-positive breast cancers, as ERs inhibit p53induced apoptosis but AIs block the signaling of ERs 
[29]. Thus, AIs were shown to produce an environment favorable to apoptosis by inhibiting the activity of ERs, although they did not inhibit apoptosis directly [29]. The results of our study, which did not show a significant increase in apoptosis in ovarian tumors following the administration of an AI, agree with the results of Bailey et al.

AIs have been shown to be more effective than tamoxifen if they are used as postoperative adjuvant therapy in breast cancers [30]. No definite conclusion, however, has yet been reached with regard to the effect of AIs in recurrent ovarian cancers. The effects of AIs on in vitro ovarian cancer cells were related to aromatase activity and estrogen receptor expression [6]. Of four clinical studies that have verified the efficacy of letrozole in recurrent ovarian cancers [31-34], three clinical studies conducted in patients with ER $\alpha$-positive recurrent ovarian cancers showed that the response rate to letrozole was $11.8 \%$ in the 102 patients [31-33]. However, the details of progression-free survival or overall survival are unknown. Adverse reactions to letrozole were slight compared to those of anticancer agents and the response rate of $11.8 \%$ is similar to that obtained with salvage chemotherapy. As shown in Figure 3, letrozole has an inhibitory effect on angiogenesis, therefore it is expected that patients with ER $\alpha$-positive recurrent ovarian cancers are candidates of letrozole administration alone or in combination with bevacizumab, a drug that targets molecules involved in angiogenesis.

Estrogen accelerates angiogenesis and is involved in the progression of tumors [35]. ER signaling inhibits apoptosis [29]. Letrozole, an AI, has been shown to exhibit an antitumor effect by inhibiting angiogenesis in $E R \alpha$-positive ovarian cancers and by inhibiting the actions of ER $\alpha$. Although the effect of letrozole on survival was statistical significant in mice, it is an important issue whether the clinical significance of the findings will be achieved. Thus, further investigation of whether Letrozole sensitizes OVCAR-3 tumour to platinum compound is warranted. AIs will likely play a central role in the establishment of a new treatment strategy in ER $\alpha$ positive ovarian cancers in the future. Clinical trials of letrozole alone or in combination with other molecular targeted drugs will be required to further evaluate the drug's efficacy in the treatment of ER $\alpha$-positive ovarian cancers.

\section{Conclusions}

Letrozole was effective for peritonitis carcinomatosa as a late stage of ovarian cancer with abundant expression of ER $\alpha$. Inhibition of angiogenesis and of ascites production appeared to contribute to prolongation of the survival period.

\section{Abbreviations}

ER: Estrogen receptor; Al: Aromatase inhibitor; VEGF: Vascular endothelial growth factor; MVD: Microvessel density.
Competing interests

The authors declare that they have no competing interest.

\section{Authors' contributions}

$\mathrm{HH}$ and $\mathrm{YY}$ conceived and designed the study, performed the experiments and wrote the paper. HM contributed to the writing and to the critical reading of the paper. HY performed RT-PCR experiment as a coach and contributed to the critical reading of the paper. All authors read and approved the final manuscript.

\section{Acknowledgements}

This study was supported in part by a Grant-in Aid for Cancer Research (No. 20591935) from the Ministry of Education, Science and Culture of Japan and by the Karoji Memorial Fund of the Hirosaki University Graduate School of Medicine. The authors thank Emiko Mizuki, M.T., Tomoko Akaishi, M.T. and Emiko Mikami, M.T. for experimental assistance.

\section{Author details}

'Department of Obstetrics and Gynecology, Hirosaki University Graduate School of Medicine, 5 Zaifu-cho, Hirosaki, Aomori 036-8261, Japan.

2Department of Vascular Biology, Institute of Brain Science, Hirosaki University Graduate School of Medicine, 5 Zaifu-cho, Hirosaki, Aomori 036-8562, Japan.

Received: 10 November 2013 Accepted: 7 January 2014

Published: 10 January 2014

\section{References}

1. Siegel R, Naishadham D, Jemal A: Cancer statistics, 2013. CA Cancer J Clin 2013, 63(1):11-30

2. Langdon SP, Hirst GL, Miller EP, Hawkins RA, Tesdale AL, Smyth JF, Miller WR: The regulation of growth and protein expression by estrogen in vitro: a study of 8 human ovarian carcinoma cell lines. J Steroid Biochem Mol Biol 1994, 50(3-4):131-135.

3. Langdon SP, Crew AJ, Ritchie AA, Muir M, Wakeling A, Smyth JF, Miller WR: Growth inhibition of oestrogen receptor-positive human ovarian carcinoma by anti-oestrogens in vitro and in a xenograft model. Eur J Cancer 1994, 30A(5):682-686.

4. Armaiz-Pena GN, Mangala LS, Spannuth WA, Lin YG, Jennings NB, Nick AM, Langley RR, Schmandt R, Lutgendorf SK, Cole SW, Sood AK: Estrous cycle modulates ovarian carcinoma growth. Clin Cancer Res 2009, 15(9):2971-2978.

5. Simpkins F, Hevia-Paez P, Sun J, Ullmer W, Gilbert CA, da Silva T, Pedram A, Levin ER, Reis IM, Rabinovich B, Azzam D, Xu XX, Ince TA, Yang JY, Verhaak RG, $L u$ Y, Mills GB, Slingerland JM: Src inhibition with saracatinib reverses fulvestrant resistance in ER-positive ovarian cancer models in vitro and in vivo. Clin Cancer Res 2012, 18(21):5911-5923.

6. Simpkins F, Garcia-Soto A, Slingerland J: New insights on the role of hormonal therapy in ovarian cancer. Steroids 2013, 78(6):530-537.

7. Pujol P, Rey JM, Nirde P, Roger P, Gastaldi M, Laffargue F, Rochefort $H$, Maudelonde T: Differential expression of estrogen receptor-alpha and -beta messenger RNAs as a potential marker of ovarian carcinogenesis. Cancer Res 1998, 58(23):5367-5373.

8. Bardin A, Hoffmann P, Boulle N, Katsaros D, Vignon F, Pujol P, Lazennec G: Involvement of estrogen receptor beta in ovarian carcinogenesis. Cancer Res 2004, 64(16):5861-5869.

9. O'Donnell AJ, Macleod KG, Burns DJ, Smyth JF, Langdon SP: Estrogen receptor-alpha mediates gene expression changes and growth response in ovarian cancer cells exposed to estrogen. Endocr Relat Cancer 2005, 12(4):851-866

10. Cunat $S$, Rabenoelina F, Daurès JP, Katsaros D, Sasano H, Miller WR, Maudelonde T, Pujol P: Aromatase expression in ovarian epithelial cancers. J Steroid Biochem Mol Biol 2005, 93(1):15-24.

11. Labrie F, Belanger A, Simard J, Van L, Labrie C: DHEA and peripheral androgen and estrogen formation: intracinology. Ann N Y Acad Sci 1995 774:16-28.

12. Slotman BJ, Kuhnel R, Rao BR, Dijkhuizen GH, De GJ, Stolk JG: Importance of steroid receptors and aromatase activity in the prognosis of ovarian cancer: high tumor progesterone receptor levels correlate with longer survival. Gynecol Oncol 1989, 33(1):76-81. 
13. Kitawaki J, Noguchi T, Yamamoto T, Yokota K, Maeda K, Urabe M, Honjo H: Immunohistochemical localisation of aromatase and its correlation with progesterone receptors in ovarian epithelial tumours. Anticancer Res 1996, 16(1):91-97.

14. Wong ZW, Ellis MJ: First-line endocrine treatment of breast cancer: aromatase inhibitor or antioestrogen? Br J Cancer 2004, 90(1):20-25.

15. Sasano H, Sato S, Ito K, Yajima A, Nakamura J, Yoshihama M, Ariga K, Anderson TJ, Miller WR: Effects of aromatase inhibitors on the pathobiology of the human breast, endometrial and ovarian carcinoma. Endocr Relat Cancer 1999, 6(2):197-204.

16. Yokoyama Y, Xin B, Shigeto T, Umemoto M, Kasai-Sakamoto A, Futagami M, Tsuchida S, Al-Mulla F, Mizunuma H: Clofibric acid, a peroxisome proliferatoractivated receptor a ligand, inhibits growth of human ovarian cancer. Mol Cancer Ther 2007, 6(4):1379-1386.

17. Meng P, Yoshida H, Matsumiya T, Imaizumi T, Tanji K, Xing F, Hayakari R, Dempoya J, Tatsuta T, Aizawa-Yashiro T, Mimura J, Kosaka K, Itoh K, Satoh K: Carnosic acid suppresses the production of amyloid- $\beta$ 1-42 by inducing the metalloprotease gene TACE/ADAM17 in SH-SY5Y human neuroblastoma cells. Neurosci Res 2013, 75(2):94-102.

18. Sakamoto A, Yokoyama Y, Umemoto M, Futagami M, Sakamoto T, Bing X, Mizunuma H: Clinical implication of expression of cyclooxygenase-2 and peroxisome proliferator activated-receptor gamma in epithelial ovarian tumours. Br J Cancer 2004, 91(4):633-638.

19. Rayoo M, Yan M, Takano EA, Bates GJ, Brown PJ, Banham AH, Fox SB: Expression of the forkhead box transcription factor FOXP1 is associated with oestrogen receptor alpha, oestrogen receptor beta and improved survival in familial breast cancers. J Clin Pathol 2009, 62(10):896-902.

20. Dabrosin C, Margetts PJ, Gauldie J: Estradiol increases extracellular levels of vascular endothelial growth factor in vivo in murine mammary cancer. Int J Cancer 2003, 107(4):535-540.

21. Hyder SM, Nawaz Z, Chiappetta C, Stancel GM: Identification of functional estrogen response elements in the gene coding for the potent angiogenic factor vascular endothelial growth factor. Cancer Res 2000, 60(12):3183-3190.

22. Nakamura J, Savinov A, Lu Q, Brodie A: Estrogen regulates vascular endothelial growth/permeability factor expression in 7,12-dimethylbenz (a)anthracene-induced rat mammary tumors. Endocrinology 1996, 137(12):5589-5596.

23. Brodie AM, Schwarzel WC, Shaikh AA, Brodie HJ: The effect of an aromatase inhibitor, 4-hydroxy-4-androstene-3,17-dione, on estrogendependent processes in reproduction and breast cancer. Endocrinology 1977, 100(6):1684-1695.

24. Fersis N, Smyczek-Gargya B, Armeanu S, Gagulic E, Pantic L, Relakis K, Friedrich $M$, Wallwiener $D$ : Changes in vascular endothelial growth factor (VEGF) after chemoendocrine therapy in breast cancer. Eur J Gynaecol Oncol 2004, 25(1):45-50.

25. Coezy E, Borgna $J$, Rochefort H: Tamoxifen and metabolites in MCF7 cells: correlation between binding to estrogen receptor and inhibition of cell growth. Cancer Res 1982, 42(1):317-323.

26. Lisztwan J, Pornon A, Chen B, Chen S, Evans DB: The aromatase inhibitor letrozole and inhibitors of insulin-like growth factor I receptor synergistically induce apoptosis in in vitro models of estrogen-dependent breast cancer. Breast Cancer Res 2008, 10(4):R56. 10.1186/bcr2113.

27. Liu Y, Zhang X, Liu J, Hou G, Zhang S, Zhang J: Everolimus in combination with letrozole inhibit human breast cancer MCF-7/Aro stem cells via PI3K/mTOR pathway: an experimental study. Tumour Biol. in press.

28. Amaral C, Varela C, Borges M, Tavares da Silva E, Roleira FM, Correia-da-Silva G, Teixeira N: Steroidal aromatase inhibitors inhibit growth of hormonedependent breast cancer cells by inducing cell cycle arrest and apoptosis. Apoptosis 2013, 18(11):1426-1436.

29. Bailey ST, Shin H, Westerling T, Liu XS, Brown M: Estrogen receptor prevents p53-dependent apoptosis in breast cancer. Proc Natl Acad Sci USA 2012, 109(44):18060-18065.

30. Cuzick J, Sestak I, Baum M, Buzdar A, Howell A, Dowsett M, Forbes JF: Effect of anastrozole and tamoxifen as adjuvant treatment for early-stage breast cancer: 10-year analysis of the ATAC trial. Lancet Oncol 2010, 11(12):1135-1141.

31. Ramirez PT, Schmeler KM, Milam MR, Slomovitz BM, Smith JA, Kavanagh J, Deavers M, Levenback C, Coleman RL, Gershenson DM: Efficacy of letrozole in the treatment of recurrent platinum- and taxane-resistant high-grade cancer of the ovary or peritoneum. Gynecol Oncol 2008, 110(1):56-59.
32. Smyth JF, Gourley C, Walker G, Mackean MJ, Stevenson A, Williams AR, Nafussi AA, Rye T, Rye R, Stewart M, McCurdy J, Mano M, Reed N, McMahon T, Vasey P, Gabra H, Langdon SP: Antiestrogen therapy is active in selected ovarian cancer cases: the use of letrozole in estrogen receptorpositive patients. Clin Cancer Res 2007, 13(12):3617-3622.

33. Papadimitriou CA, Markaki S, Siapkaras J, Vlachos G, Efstathiou E, Grimani I, Hamilos G, Zorzou M, Dimopoulos MA: Hormonal therapy with letrozole for relapsed epithelial ovarian cancer. Long-term results of a phase II study. Oncology 2004, 66(2):112-117.

34. Bowman A, Gabra H, Langdon SP, Lessells A, Stewart M, Young A, Smyth JF: CA125 response is associated with estrogen receptor expression in a phase II trial of letrozole in ovarian cancer: identification of an endocrine-sensitive subgroup. Clin Cancer Res 2002, 8(7):2233-2239.

35. lyer V, Klebba I, McCready J, Arendt LM, Betancur-Boissel M, Wu MF, Zhang X, Lewis MT, Kuperwasser C: Estrogen promotes ER-negative tumor growth and angiogenesis through mobilization of bone marrow-derived monocytes. Cancer Res 2012, 72(11):2705-2713.

doi:10.1186/1757-2215-7-4

Cite this article as: Hirakawa et al:: Inhibitory effects of aromatase inhibitor on estrogen receptor-alpha positive ovarian cancer in mice. Journal of Ovarian Research 2014 7:4.

\section{Submit your next manuscript to BioMed Central and take full advantage of:}

- Convenient online submission

- Thorough peer review

- No space constraints or color figure charges

- Immediate publication on acceptance

- Inclusion in PubMed, CAS, Scopus and Google Scholar

- Research which is freely available for redistribution

Submit your manuscript at www.biomedcentral.com/submit
C) Biomed Central 